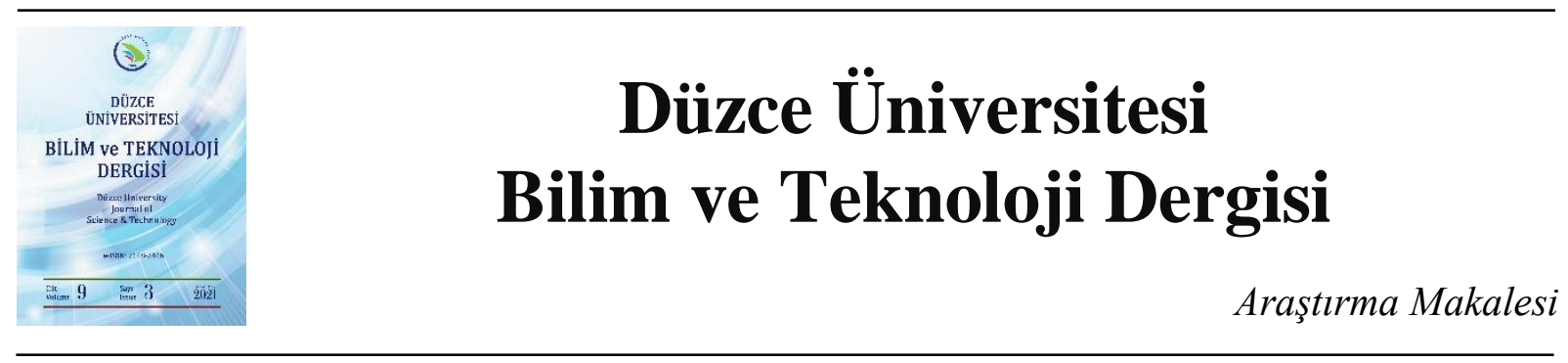

\title{
Orman Mühendisliği Meslek Alanında Yayımlanan Orman Mühendisliği ve Yeşil Dünya Dergilerinin İncelenmesi
}

\author{
Ayşe Tuğçe BULUT ${ }^{a,}$, (iD Yaşar Selman GÜLTEKIN ${ }^{\text {b,* }}$ \\ ${ }^{a}$ Orman Mühendisliği Anabilim Dal, Fen Bilimleri Enstitüsü, Düzce Üniversitesi, Düzce, TÜRKIYYE \\ ${ }^{b}$ Orman Mühendisliği Bölümü, Orman Fakültesi, Düzce Üniversitesi, Düzce, TÜRKİYE \\ * Sorumlu yazartn e-posta adresi: selmangultekin@duzce.edu.tr \\ DOI: $10.29130 /$ dubited.898913
}

\begin{abstract}
ÖZET
Bu çalışmanın amacı, Orman Mühendisleri Odası (OMO) tarafından yayımlanan ve orman mühendisliği mesleği ile ilgili olan Orman Mühendisliği ve Yeşil Dünya dergilerinin 1962-2020 yılları arasındaki sayılarının içerik olarak hangi konularda odaklandığını ortaya koymaktır. 2005-2020 yıllarının içerik analizinde ise ayrıca MAXQDA 2020 programından yararlanılmıştır. Çalışma kapsamında ele alınan 467 adet sayıda yayımlanan başlıca konular sistematik bir şekilde incelenerek içeriklerinde hangi konulara değinildiğinin ve konular arasındaki ilişkilerin değerlendirmesinde içerik analizi yöntemi kullanılmıştır. Çalışma bulguları toplamda 5245 adet konudan bahsedildiğini ve bu konuların orman mühendisliğinin alt bilim dallarıyla ilişkili olanlarının sayısının 2008, Odadan haberler-Kongreler ve Genel konularının sayısının ise 3237 olduğunu göstermektedir. Yapılan içerik analizine göre, 2005-2020 yılları arasında en çok kullanılan kelimelerin orman, mühendis, ağaç, ormancılık, toprak, tür, doğa, kanun, yangın ve mühendislik olduğu belirlenmiştir. Çalışma sonucunda Orman Mühendisliği ve Yeşil Dünya dergilerinin içerikleri ve ele alınan konular hakkında değerlendirmeler yapılmıştır. Elde edilen sonuçlara göre, dergilerde en çok OMO'nun faaliyetlerine yer verildiği görülmüştür. Yapılan içerik analizinde ise, orman mühendisi, orman yangını, orman alanı, orman ekosistemi, tohum bahçeleri vb. dikkat çekici kelime kombinasyonlarının olduğu anlaşılmıştır. OMO'nun dergilerde oda faaliyetlerini daha sade ele alarak ormancılık alanında daha fazla bilgi ve sorunlara yer vermesi önerilmektedir.
\end{abstract}

Anahtar Kelimeler: Orman Mühendisliği Dergisi, Yeşil Dünya Dergisi, Orman Mühendisleri Odası, Içerik Analizi.

\section{Review of Forest Engineering and Green World Journals Published in the Forest Engineering Profession}

\begin{abstract}
The aim of this study is to reveal that the issues of Forest Engineering and Yeşil Dünya magazines published by the Chamber of Forest Engineers between 1962 and 2020 focus on the content of the forest engineering profession. The MAXQDA 2020 program was used in the content analysis of the years 2005-2020 separately. The content analysis method was used to evaluate which subjects were addressed in their contents and the relations between them by systematically examining the main issues that were published in 467 issues within the scope of the study. The findings showed that a total of 5245 topics were mentioned, and the number of these topics related to forest engineering sub-disciplines was 2008, and the number of news about the Chamber, Congress and General issues was 3237. According to content analysis, it was determined that the most used words between 2005 and 2020 were forest, engineer, tree, forestry, soil, species, nature, law, fire and engineering. As a result of the study, evaluations were made about the contents of Forest Engineering and Yeşil Dünya journals and the topics covered. According to the results, it was seen that the activities of OMO were mostly included in the magazines. In the content analysis,
\end{abstract}


forest engineer, forest fire, forest area, forest ecosystem, seed orchards, etc. remarkable word combinations have been found. It is recommended that OMO should include more information and problems in the field of forestry by considering chamber activities more simply in magazines.

Keywords: Orman Mühendisliği Magazine, Yeşil Dünya Magazine, Chamber of Forest Engineers, Content Analysis.

\section{GIRIS}

İnsanların tarih boyunca yeryüzündeki yaşam ortamlarına duyduğu merak dürtüsü modern bilimin temellerinin atılmasını sağlamıştır. Bilim, öncelikle sistematik bilgiler topluluğudur. Bu bilgiler olgusal ve mantıksal açıdan bir bütündür. İnsan, dünyada karşılaştığı nesneleri bilmek ister. Bu nesneler ile insan arasındaki etkileşim sonunda ortaya çıkan ürüne bilgi denir [1]. Bilgi sözcüğünün sözlü dönemden yazılı döneme ve matbaanın bulunmasının ardından dijital yayımcılığa geçilmesiyle, kitaplaşma dönemi ve yayımcılık düşünceleri de farklılaşmaya başlamıştır [2].

Yayın kavramı Türk Dil Kurumu (TDK)'ya göre; "radyo televizyon aracılığıyla halka sunulan, duyurulan, iletilen eser, program, basılıp satışa çıkarılan kitap, gazete vb., neşriyat", yayım ise "kitap, gazete vb. okunacak şeylerin basılıp dağıtılması" olarak tanımlanmaktadır [3]. Diğer bir ifadeyle yayın; internet, televizyon ve radyo kanallarıla topluma sunulan ya da basılan dergi, gazete gibi okunan bütün gereçler olarak tanımlanmaktadır [4]. Sıklıkla okunan, basılı olan gazeteler ve dergiler gibi televizyonlara kadar bütün faaliyetler yayımcılık kapsamındadır. Tarihsel bilgilerin saf halde derlenip toparlanmasında, kamuoyu oluşturmada ve toplumsal mirasların kuşaklar arası aktarımında yayımcılığın önemi büyüktür. Teknolojinin gelişmesiyle ilk olarak yazılı, daha sonra işitsel ve son olarak görsel yayımcılığı insanların tanıdığı bilinmektedir [5].

Türkiye'de yayım faaliyetlerinin, batı ülkelerinde yayımcılığın ve ticaretin gelişmesi ile ekonomik ihtiyacı karşılamak amacıyla ortaya çıktığı ve geliştiği ifade edilmektedir [6]. Yayımcılık içeriklerine, hedef kümelerine ve ulaşllabilirliklerine göre bölümlendirilebilir. Buna göre yayımlar; haber, iktisat ve magazin gibi içeriklerde gazete, dergi, televizyon veya radyo programları olarak sınıflandırılabilir [7].

1700'lü yılların sonlarına doğru Türkiye'de dergi yayımcılığının başladığı belirtilmektedir. Osmanlı döneminde ilk yabancı dildeki dergi 1795 'te yayımlanan "Bulletin de Nouvelles" olarak bilinmektedir. Türkçe dergilerin yayımlanması için ise yaklaşık yarım asır geçtiği bildirilmektedir [8]. 1849'da Türkiye' de yayımlanan ilk Osmanlıca-Türkçe derginin, tıp alanında "Vekayi-i Tıbbiye" isimli bir dergi olduğu bilinmektedir. Vekayi-i Tıbbiye dergisinden sonra 1862 yılında çıkarılan "Mecmua-i Fünun" adlı dergi, derginin sahibi Münif Paşa'nın "Cemiyet-i İlmiye-i Osmaniye" ismiyle kurduğu bir derneğin iletişim aracı olarak çıkarıldığı düşünülmektedir [9].

Türkiye'de ormancılık üzerine ilk dergiciliğin örneği olarak "Mecmua-i Fünun" verilebilir [10]. Osmanlı döneminin ilk popüler bilim dergisi olan "Mecmua-i Fünun"da 1864 yılında yayımlanan 32. sayısında ormancılıkla ilgili ilk basılmış makale, yazarı Mehmet Nazif Bey olan "Orman Bilimi"dir [11].

Türkiye İstatistik Y1llığ 2019 verilerine göre; 2018 yılına göre \%8,0 azalarak yılda 5 bin 485 civarında akademik, popüler, haber dergileri ve gazeteler yayımlanmaktadır. Bu yayımcılık faaliyetlerinin $\% 57,4$ 'ü dergi kategorisindedir [12]. Bununla birlikte, Türkiye'de ormancılık alanında yayımlanan ilk dergi olan "Orman ve Av" dergisi 1928 yılından beri düzenli olarak yayımlanmaktadır [13].

Orman mühendisliği mesleğinin 150 ylldan fazla bir geçmişe sahip olduğu bilinmektedir [14]. Türkiye' de ise, Fransız ormancıların katkılarıyla 1857 yılında ormancılık eğitiminin verilmesi amacıyla 
kurulan, orman okulu ile ilk orman mühendislerinin yetiştirilmeye başlandığı bilinmektedir. Halkalı Ziraat Okulu ve Orman Okulu, Tanzimat Dönemi'ndeki ilk mühendislik okulları arasındadır. Orman Mektebi sonradan Orman Mektebi Ali'sine dönüşerek, 1933'te kurulan Yüksek Ziraat Enstitüsü'ne bağlanmış, 1948'de Enstitü' den ayrılarak İstanbul Üniversitesi yapısı altında Orman Fakültesi olarak yer almıştır [14]. Ayrıca Türkiye tarihi açısından önemli bir yeri olan ilk ormancılık teşkilatı da "Orman Müdürlügü̈" adıyla Ticaret Nezaretine bağlı olarak 1839'da İstanbul'da kurulmuştur [15].

Orman mühendislerinin ilk mesleki kuruluşu “Türk Mühendis ve Mimar Odaları Birliği” (TMMOB)'nin de üyesi olan Orman Mühendisleri Odası (OMO)'dır [16]. OMO, 1954 yılında Orman Mühendisi, Ağaç İşleri Endüstri Mühendisi ve Orman Endüstri Mühendislerini bir çatı altında toplamak amacıyla kurulan tüzel kişiliğe sahip bir kuruluştur [17]. OMO "Orman Mühendisliği” dergisini, ilk olarak 1962 yılının Nisan ayında yayımlamaya başlamıştır [18]. OMO’nun, Orman Mühendisi, Ağaç İşleri Endüstri Mühendisi ve Orman Endüstri Mühendislerinden oluşan bir kurum olmas1 nedeniyle Orman Mühendisliği adıyla yayımladığı dergisinin ismini sadece Orman Mühendisliği mesleğini belirttiği gerekçesiyle 2018 yılında "Yeşil Dünya" olarak değiştirmiştir [17].

Bu çalışmanın amacı, Orman Mühendisliği ve Yeşil Dünya dergilerinin 1962-2020 yılları arasındaki sayılarının içerik olarak hangi konularda odaklandığını ortaya koymaktır.

\section{MATERYAL VE YÖNTEM}

$\mathrm{Bu}$ araştırmanın ana materyalini merkezi Ankara'da bulunan OMO'nun arşivinden ve resmi internet adresinden (https://ormuh.org.tr/) elde edilen "Orman Mühendisliği ve Yeşil Dünya” dergilerine ilişkin veriler oluşturmaktadır. Araştırma kapsamında ikincil veri kaynaklarından yararlanılmıştır.

$\mathrm{Bu}$ çalışmanın başlangıç aşamasında $\mathrm{OMO}$ genel merkezinden yetkililer ile iletişime geçilerek Orman Mühendisliği dergilerinin 1962-2005 yılları arasındaki tüm sayılarına ulaşabilmek için randevu talep edilmiştir. OMO'dan gelen olumlu yanıt ile, Ankara'da bulunan OMO'nun genel merkezine 24 Temmuz 2018 tarihinde bir ziyaret gerçekleştirilmiştir. Yapılan ziyarette yapılması planlanan çalışma hakkında bilgilendirme yapılarak tüm sayılara erişim talep edilmiştir. Verilen onayın ardından, doküman incelemesinin birinci aşamasını oluşturan Orman Mühendisliği dergilerinin 1962-2005 yılları arasındaki sayılarına OMO’nun kütüphanesinden erişim sağlanmıştır.

OMO kütüphanesindeki Orman Mühendisliği dergileri 1962 y1lından 2005 yılına kadar olan sayıların bütün sayfaları cep telefonu kamerası yardımıyla okunaklı olacak şekilde fotoğraflanarak elde edilmiştir. Her sayının fotoğraflama işlemi bittiğinde bilgisayara önce sayı, daha sonra yıllar olarak sistematik bir şekilde veri kaybına yol açmayacak şekilde aktarılmıştır. Ayrıca fotoğraflama sırasında bazı dergi ve sayılara arşivde bulunamadığından ulaşılamamıştır. Yııllar, toplam dergi sayıları ve eksik sayılar (27 adet) kısa notlarla birlikte Microsoft Excel programına not edilmiş ve daha sonra tablo haline getirilmiştir. OMO'dan 1962-2005 yılları arasındaki verilerin fotoğraflama yoluyla temini yaklaşık 5 gün sürmüştür. 2005-2020 yılları arasındaki verilerin temini ise OMO'nun resmi internet adresinden (https://ormuh.org.tr) PDF (Taşınabilir Belge Formatı) olarak indirilerek bilgisayar ortamına kaydedilmiştir.

Elde edilen verilerin analiz edilebilmesi için öncelikle tüm dergilerin sayılarında ele alınan başlıca konuların Türkiye' deki orman mühendisliği bölümlerinde ortak olan bilim dalları ve derginin içeriğinde sıklıkla ele alınan konu başlıkları baz alınarak sistematik bir şekilde kategorize edilmiştir. Bilim dalları ve konu başlıkları; orman ekonomisi, silvikültür, orman amenajmanı, havza yönetimi, mera, milli parklar, ormanc1lık toplantıları, orman endüstrisi, odadan haberler, genel konular ve eğitim olarak belirlenmiştir. Veriler konularına göre ayrıştırıldıktan sonra dergilerde ele alınan konuların ve konular arasındaki ilişkilerin değerlendirmesi yapılarak ele alınan konuların içerikleri arasındaki ilişkiler yııllara göre periyodik ve kronolojik olarak sınıflandırılarak değerlendirmeler yapılmıştır. 
1962-2005 yıllarına ait dergi verileri yıllar ve sayılar bazında sırayla okunarak dergilerde yer alan makalelerin içeriklerinin belirlenerek orman mühendisliğinin bilim dallarına ve konulara göre sınıflandırması yapılmıştır. Bu çalışmada makale temelli bir analiz yapılmıştır. Dergilerde yer alan makaleler tek bir konu altında ele alınmıştır. Makalelerin içerikleri okunarak konunun başlıca neye değindiği saptanmış ve buna göre hangi bilim dalının içeriği olduğu kontrol edilerek belirlenmiştir. Birden fazla konunun birlikte ele alındığ yapılmıştır. Ayrıca, elde edilen dergi verileri yıllar ve konular itibariyle 10'ar yıllık periyotlarla Microsoft Excel programında tablolaştırılarak açıklayıcı grafikler oluşturulmuştur.

Çalışmanın son aşamasında ise, içerik analizi yöntemi ile 2005-2020 yılları arasında yayımlanan dergilerin içerik incelemesi yapılmıştır. İçerik analizi yöntemi, herhangi bir ifadeyi idrak etmede, yorumlamada, sübjektif faktörlerden kurtulma amacıyla kullanılmaktadır. Bu yöntem ile, ifadelerinin açıkça görünen, ilk bakışta basitçe anlaşılan içeriği yerine, daha saklı ve üstü örtülü içeriğini meydana çıkarmaktadır. Diğer bir ifadeyle içerik analizi, verilmek istenen düşüncede, konunun içeriğindeki unsurların daha objektif bir şekilde tayin edilmesine yönelik "ikinci bir okuma"dır. Bu okuma, yeni bir şeyler öğreten ve yeni bir bakış açısı oluşturmaya katkı sağlayan bir okuma biçimidir. Ayrıca düşüncelerde incelenen ve tasvir edilen unsurlardan hareketle daha detaylı açıklama amacını taşımaktadırlar [19]. İçerik analizi yönteminde sabırlı olmak ve titiz çalışmak gerekir. Öyle ki "gerç eğin basit okuması" güzel olmakla birlikte yeterli değildir. İçerik analizi yöntemleri iki amaca hizmet etmeye yöneliktir:

- Mutlak bilgi edinme ve şüpheleri yok etmek,

- Elde edilen metni zenginleştirmek ve görüşü genişletmek [20].

İçerik analizi yönteminin uygulanması, bazı aşamalardan meydana gelmektedir. İlk olarak araştırmanın gayesi belirlenmelidir. Hedef veya amaçların tespit edilmesi, enerji ve zaman tasarrufu sağlamaktadır. İkinci aşamada örneklem oluşturulmalıdır. Oluşturulacak örneklem sınırlı sayıda dergi, film, gazete ve diğer iletişim türlerinden oluşabilmektedir. Üçüncü aşamada ise, örneklemin ayrılacağı hususlar, birimler veya kayit birimleri ve kategoriler tespit edilir. Birimlerin ve kategorilerin sıklıkları miktar olarak belirlendikten sonra, "değerlendirme, sonuç ve yorumlama" aşamasına gelinmiş olur [19].

Bir çalışmada uygulanacak olan içerik analizi için aşağıdaki 6 soru önemlidir ve analizde bu sorulara cevap aranmalıdır [21].

- Çözümlemesi yapılacak veriler hangileridir?

- Veriler nasil tanımlanır?

- Çıkarımların amacı nedir?

- Analizi yapılan verilerin içerikleri nelerdir?

- Çözümlemenin sınırları nelerdir?

- İşlenmiş verinin örneklemi nedir

Orman Mühendisliği ve Yeşil Dünya dergilerinin 2005-2020 yılları arasındaki PDF dosyaları şeklinde elde edilen tüm sayılarına içerik analizi yöntemi MAXQDA 2020 programından yararlanılarak uygulanmıştır. Metin içerisinde geçen bölümleri olduğu gibi kodlamaya yarayan (In-vivo) seçeneği kullanılarak kelime kodlamaları yapılmıştır [22]. MAXQDA programına aktarılan PDF dosyaları 20052010, 2011-2015 ve 2016-2020 yıllarını içerecek şekilde kelime frekanslarına bakılmıştır. Kelime frekanslarına göre tek başına anlam ifade etmeyen ve direk ormancılık konularılya alakalı olmayan kelimeler (ve, ile, ancak vb.) frekans tablosunun dışında bırakılmıştır. Ormancılık ile ilgili anlam ifade eden kelimeler önce kelime frekansları yapılmış, daha sonra ikili ve üçlü olarak "kelime kombinasyonları" oluşturulmuştur. Frekansına bakılan bu kelimelerin sıklık ve yüzdeleri hesaplanmıştır. Hesaplanan kelime öbekleri hem Tablolar halinde hem de kelime öbeklerinin sıklık ve yüzdelerine göre MAXQDA programı aracılığı ile "kelime bulutları" oluşturularak analiz edilmiştir. Fakat ikili ve üçlü kelime kombinasyonları için kelime bulutuna yer verilmemiştir. 
Orman Mühendisliği dergisinin 27 sayısının arşivde olmamasından dolayı bu sayılar çalışmanın değerlendirme kapsamı dışında kalmıştır. Ayrıca arşivde dergi sayılarının bazı sayfalarının eksik olduğu görülerek not edilmiştir.

\section{BULGULAR VE TARTIȘMA}

Çalışma kapsamında yapılan araştırma ile 1962-2020 yılları arasında yayımlanmış 495 adet dergi sayısına ulaşılmıştır. Orman Mühendisliği dergisinin bazı sayılarının arşivde olmamasından dolayı bu sayılar çalışmanın değerlendirme kapsamı dışında kalmıştır. Orman Mühendisliği dergilerinden 27 adet sayı arşivde bulunamamıştır. Aslan [23] tarih alanında yaptığı çalışmada da 17 nüsha olarak yayımlanmış olan gazeteden sadece 14 nüshasına ulaşılarak bir içerik analizi yapılmıştır. Ayrıca arşivde dergi sayılarının bazı sayfalarının eksik olduğu görülerek not edilmiştir. Yapılan incelemede ulaşılan dergilerin içeriğinde toplam konu başlıklarının sayısının 5663 olduğu belirlenmiştir.

Orman Mühendisliği ve Yeşil Dünya dergilerine yönelik yapılan çalışmalar onar yıllık zaman dilimlerine ayrilarak (1962-1970, 1971-1980, 1981-1990, 1991-2000, 2001-2010 ve 2011-2020), bu yıllar arasındaki ulaşılabilen tüm sayılarının içerikleri analiz edilmiştir.

Orman Mühendisliği ve Yeşil Dünya dergilerinin 1962-2020 yılları arasındaki içeriklerinde toplamda 4917 adet konu başlığına ulaşılmıştır. Çelikel [24] sosyoloji alanında yaptığı bir çalışmada 19 farklı derginin toplamda 503 sayısı ve bu sayılarda da 5543 adet konu başlığına yer verilmiş ve sadece konu başlıkları herhangi bir program kullanılmadan analiz edilmiştir.

Çalışma kapsamında konular 12 bölüme ayrılmıştır. Bu bölümlerden 9 tanesi orman mühendisliği bölümünün bilim dallarına ait iken diğer 3 adedi ise odadan haberler ve genel konulardır. Orman Mühendisliği dergisinin 1962-2020 yılları arası konularına göre dağılımı Tablo 1'de verilmiştir.

Tablo 1. Orman mühendisliği dergisinin 1962-2020 yılları arası konularına göre dă̆ılımı

\begin{tabular}{|c|c|c|c|c|c|c|c|}
\hline \multirow[b]{2}{*}{ Bilim dalları/Konular } & \multicolumn{6}{|c|}{ Yillar } & \multirow[b]{2}{*}{ Toplam } \\
\hline & 1962-1970 & 1971-1980 & 1981-1990 & 1991-2000 & 2001-2010 & 2011-2020 & \\
\hline Genel & 174 & 257 & 702 & 451 & 351 & 271 & 2032 \\
\hline Odadan haberler & 152 & 232 & 330 & 155 & 89 & 58 & 864 \\
\hline Silvikültür & 125 & 137 & 261 & 128 & 85 & 56 & 667 \\
\hline Orman ekonomisi & 104 & 108 & 109 & 76 & 96 & 29 & 418 \\
\hline Havza yönetimi & 52 & 51 & 87 & 64 & 20 & 21 & 243 \\
\hline Orman amenajmanı & 35 & 32 & 60 & 52 & 14 & 16 & 174 \\
\hline Orman endüstrisi & 31 & 24 & 46 & 45 & 13 & 16 & 144 \\
\hline $\begin{array}{l}\text { Orman entomolojisi ve } \\
\text { koruma }\end{array}$ & 29 & 20 & 37 & 34 & 12 & 11 & 114 \\
\hline Eğitim & 18 & 13 & 36 & 30 & 8 & 16 & 103 \\
\hline $\begin{array}{l}\text { Orman inşaatı jeodezi ve } \\
\text { fotogrametri }\end{array}$ & 17 & 10 & 37 & 24 & 6 & 7 & 84 \\
\hline Milli parklar & 7 & 9 & 25 & 10 & 3 & 5 & 52 \\
\hline Ormancılık toplantıları & 2 & 3 & 12 & 4 & 0 & 3 & 22 \\
\hline TOPLAM & 746 & 896 & 1742 & 1073 & 697 & 509 & 4917 \\
\hline
\end{tabular}

Tablo 1'e göre; Orman Mühendisliği dergisinin 1962-1970 yılları arasında konulara göre dağılımı değerlendirildiğinde, Orman amenajman kadastrosu ve hasılatı (35), Eğitim (18), orman ekonomisi 
(104), Genel (174), Havza yönetimi (52), Milli parklar (7), Odadan haberler (152), Ormancilik toplantılar1 (2), Orman endüstrisi (31), Silvikültür (125), Orman inşaatı, jeodezi ve fotogrametri (17), Orman entomolojisi ve koruma (29) adet olmak üzere toplamda 746 adet konu içeriğinin olduğu tespit edilmiştir. Orman mühendisliğinin bilim dalları göz önüne alındığında 1962-1970 yılları arasında en fazla silvikültürel uygulamalara ilişkin konuların ele alındığı görülmektedir. 1962-1970 yılları arasındaki konuların dağılım ve sayılarına bakıldığında diğer yıllara göre en az konunun ele alındığı yılın 43 konu ile derginin ilk yayımlandığı yıl olan 1962 yılı olduğu görülmüştür. Aynı yıl aralığında en fazla 113 konuyla 1969 yılında yer verildiği belirlenmiştir.

Orman Mühendisliği dergisinin 1971-1980 arasındaki konu dağılımları bilim dalları bazında en az yer verilen konuların 3 adet konu ile "milli parklar" olduğu anlaşılmaktadır. Ayrıca en çok içeriği olan konuların ilk sirasında 257 ile "genel" bilgiler, ardından bu konuyu 232 ile "odadan haberler" takip etmektedir. Fakat bilim dalları olarak bakıldığında en fazla 137 ile orman ekonomisi konularının ilk sırada yer aldığ belirlenmiştir. Tablodaki veriler yıl bazında ele alındığında en fazla 1975 yılında, en az ise 1980 yılında konu sayılarına yer verilmiştir. 1977 yılına ait Orman Mühendisliği dergisi verilerine OMO arşivinde bulunamadığı gibi başka yerlerde yapılan araştırmalar sırasında da ulaşılamamıştır. Bu durum dikkat çekmektedir.

Orman Mühendisliği dergisinin 1981-1990 yılları arası konularına göre dağılımlarına bakıldığında toplamda 1742 adet konu yer almıştır. Tablo genelinde en fazla konu içeriğine sahip olarak ilk sırada 702 ile "odadan haberler", ardından bu konuyu 261 ile "genel" bilgiler takip etmektedir. Fakat bilim dalları olarak bakıldığında en fazla 330 ile silvikültür konularının ilk sırada yer aldığı, en az içeriği olan konuların ise 12 ile "ormancılık toplantıları" alanında olduğu görülmektedir. Veriler yıl bazında ele alındığında en fazla 1985 yılında, en az ise 1981 yılında konu sayılarına yer verilmiştir.

Orman Mühendisliği dergisinin 1991-2000 yılları arası konularına göre dağılımına bakıldığı zaman dağılımları bilim dalları bazında en az yer verilen konuların 4 adet konu ile "orman inşaatı jeodezi ve fotogrametri" olduğu görülmektedir. Fakat bilim dalları olarak en çok konu içeren ise 155 konu ile silvikültür ilk sırada yer aldığ 1 belirlenmiştir. Ayrıca en çok içeriği olan konuların ilk sırasında 451 ile "odadan haberler", ardından bu konuyu 128 ile "genel" bilgiler takip etmektedir. Tablodaki veriler yıl bazında ele alındığında en fazla 1991 yılında, en az ise 1997 yılında konu sayılarına yer verilmiştir.

Orman Mühendisliği dergisinin 2001-2010 yılları arası konularına göre dağılımına göre; incelenen tabloda bilim dalları bazında en az bahsedilen alanın ise 3 adet konu ile "orman inşaatı jeodezi ve fotogrametri" alanında olduğu anlaşılmaktadır. Ayrıca en çok içeriği olan konuların ilk sırasında 351 ile "odadan haberler" ardından bu konuyu 89 ile "genel" bilgiler takip etmektedir. Dikkat çeken konulardan birisi, toplam konu sayısı 697 olduğuna göre konuların yaklaşık yarısını "odadan haberler" içermektedir. Ayrıca, bilim dallarına göre bakıldı̆̆ 1 zaman en çok bahsedilen bilim dalı 85 ile "silvikültür" ilk sıralarda görülmektedir. Veriler yıl bazında bakıldığında en fazla 2008 yılında, en az ise 2004 yılında konu sayılarına yer verilmiştir.

Orman Mühendisliği dergisinin 2011-2020 yılları arası konularına göre dağılımı incelendiğinde bilim dalları bazında en az yer verilen konuların "eğitim" ( 3 adet) ve "orman amenajman, kadastrosu ve hasılatı" 5 adet, ve "orman inşaatı jeodezi ve fotogrametri" konulardan 7 defa bahsedilmiştir. Ayrıca bilim dalları olarak bakıldığında 56 konu ile "silvikültür" konularının ilk sırada yer aldığı belirlenmiştir. Fakat en çok içeriği olan konuların ilk sırasında 271 ile "odadan haberler" yer almaktadır. Diğer bir ifadeyle toplam konuların yaklaşık yarısını odadan haberler bölümü oluşturmaktadır. Veriler yıl bazında ele alındığında en fazla 2011 yılında, en az ise 2017 yılında konu sayılarına yer verilmiştir.

$\mathrm{Bu}$ bölümde ise MAXQDA programı ile 2005-2020 yılları arasındaki dergiler içerik analizine tabi tutulmuştur. Buna göre, 2005-2010 yılları arası Orman Mühendisliği dergisinin içerik analizi ile elde edilen bulguları Tablo 2'de verilmektedir. 
Tablo 2. 2005-2020 yıllart kelime frekanslart

\begin{tabular}{|c|c|c|c|c|c|c|c|c|}
\hline & $5-2010$ & & & 2011-2 & 015 & & & \\
\hline Kelime & Frekans & $\%$ & Kelime & Frekans & $\%$ & Kelime & Frekans & $\%$ \\
\hline orman & 9307 & 361,44 & orman & 8960 & 25,72 & orman & 6153 & 22,68 \\
\hline mühendis & 2323 & 90,21 & mühendis & 1491 & 4,28 & ağaç & 1357 & 5 \\
\hline ağaç & 1696 & 65,86 & ormancilık & 1477 & 4,24 & mühendis & 1248 & 4,6 \\
\hline ormancilık & 1519 & 58,99 & ağaç & 1464 & 4,20 & tür & 867 & 3,2 \\
\hline toprak & 1187 & 46,1 & mühendislik & 1342 & 3,85 & doğa & 710 & 2,62 \\
\hline kanun & 1158 & 44,97 & kanun & 1005 & 2,89 & ormancilık & 631 & 2,33 \\
\hline yangin & 1104 & 42,87 & üretim & 718 & 2,06 & bitki & 598 & 2,2 \\
\hline çevre & 974 & 37,83 & eğitim & 656 & 1,88 & toprak & 518 & 1,91 \\
\hline bitki & 855 & 33,2 & toprak & 622 & 1,79 & doğal & 500 & 1,84 \\
\hline türler & 848 & 32,93 & yönetim & 622 & 1,79 & mühendislik & 479 & 1,77 \\
\hline arazi & 750 & 29,13 & yönetmelik & 608 & 1,75 & yangilar & 477 & 1,76 \\
\hline odun & 704 & 27,34 & doğal & 591 & 1,70 & Türkiye & 453 & 1,67 \\
\hline yönetim & 681 & 26,45 & işletme & 591 & 1,70 & tohum & 424 & 1,56 \\
\hline üretim & 664 & 25,79 & odun & 562 & 1,61 & endüstri & 421 & 1,55 \\
\hline yönetmelik & 606 & 23,53 & tür & 555 & 1,59 & eğitim & 411 & 1,52 \\
\hline mücadele & 577 & 22,41 & bitki & 554 & 1,59 & kanun & 385 & 1,42 \\
\hline endüstri & 445 & 17,28 & endüstri & 519 & 1,49 & yönetim & 376 & 1,39 \\
\hline eğitim & 435 & 16,89 & arazi & 510 & 1,46 & yönetmelik & 358 & 1,32 \\
\hline işletme & 430 & 16,7 & yangın & 454 & 1,30 & mücadele & 355 & 1,31 \\
\hline köy & 421 & 16,35 & çevre & 429 & 1,23 & işletme & 351 & 1,29 \\
\hline
\end{tabular}

Tablo 2'ye göre; 2005-2010 yılları arasında en fazla kullanılan kelime öbeklerinin ilk beş tanesinin orman, mühendis, ağaç, ormancılık ve toprak olduğu görülmektedir. Tablo 2 kelime frekanslarının ilk yirmisi ele alınarak oluşturulmuştur. Ayrıca ikili kelime kombinasyonları da ilk 25 kelime ele alınarak oluşturulmuştur (Tablo 3). Çalışmada mühendis sözcügünden $(n=2323)$ defa bahsedilmiştir. Ayrıca, 2005-2020 yılları arası derginin içerik analizi ile elde edilen ilk 50 kelimeyi içeren kelime bulutu Şekil 1 'de verilmiştir.

Tablo 3. 2005-2020 yıllart ikili kelime kombinasyonlart

\begin{tabular}{|c|c|c|c|c|c|c|c|c|}
\hline \multicolumn{3}{|c|}{$2005-2010$} & \multicolumn{3}{|c|}{ 2011-2015 } & \multicolumn{3}{|c|}{ 2016-2020 } \\
\hline $\begin{array}{l}\text { Kelime } \\
\text { kombinasyonu }\end{array}$ & Frekans & $\%$ & $\begin{array}{l}\text { Kelime } \\
\text { kombinasyonu }\end{array}$ & Frekans & $\%$ & $\begin{array}{l}\text { Kelime } \\
\text { kombinasyonu }\end{array}$ & Frekans & $\%$ \\
\hline orman mühendisi & 390 & 133,56 & orman mühendisi & 226 & 89,33 & orman mühendisi & 184 & 92,00 \\
\hline orman yangını & 185 & 63,36 & orman alanı & 212 & 83,74 & ağaç türü & 131 & 65,50 \\
\hline orman alan1 & 157 & 53,77 & ağaç türleri & 111 & 43,87 & orman yangın 1 & 109 & 54,50 \\
\hline ağaç türü & 122 & 41,78 & orman ekosistemi & 111 & 43,87 & tohum bahçeleri & 90 & 45,00 \\
\hline orman amenajmanı & 119 & 40,75 & odun hammaddesi & 99 & 39,13 & orman alanı & 90 & 45,00 \\
\hline orman kanununu & 109 & 30,49 & orman kanunu & 93 & 36,76 & ehrami karaçamı & 83 & 41,50 \\
\hline ormanlik alan & 84 & 28,77 & orman köylüsü & 85 & 33,60 & orman ağaçları & 49 & 24,50 \\
\hline kabuk böcekleri & 83 & 28,42 & orman yanginı & 83 & 32,81 & orman amenajmanı & 34 & 17,00 \\
\hline odun üretimi & 82 & 28,08 & orman köyü & 68 & 26,88 & orman bitkileri & 29 & 14,50 \\
\hline
\end{tabular}


Tablo 3. (devam) 2005-2020 yıllart ikili kelime kombinasyonlart

\begin{tabular}{|c|c|c|c|c|c|c|c|c|}
\hline orman ekosistemi & 80 & 27,40 & orman amenajmanı & 57 & 22,53 & orman köylüsü & 28 & 14,00 \\
\hline orman köylüsü & 77 & 26,37 & orman ağacı & 45 & 17,79 & orman kanunu & 27 & 13,50 \\
\hline orman ağaçları & 66 & 22,60 & ormancılık eğitimi & 41 & 16,21 & trüf mantarı & 26 & 13,00 \\
\hline odun hammaddesi & 56 & 19,18 & orman bitkileri & 31 & 12,25 & Anadolu karaçamı & 24 & 12,00 \\
\hline fidan üretimi & 55 & 18,83 & odun üretimi & 30 & 11,86 & yangınla mücadele & 23 & 11,50 \\
\hline orman işletmeleri & 40 & 13,70 & orman toprağ1 & 30 & 11,86 & hukuk mücadelesi & 22 & 11,00 \\
\hline bitki türleri & 34 & 11,64 & orman yönetimi & 30 & 11,86 & doğal orman & 19 & 9,50 \\
\hline orman toprağ1 & 31 & 10,62 & fidan üretimi & 27 & 10,67 & odun üretimi & 18 & 9,00 \\
\hline orman yönetimi & 29 & 9,93 & ormancılık politikası & 26 & 10,28 & orman ekosistemi & 16 & 8,00 \\
\hline tıbbi bitki & 27 & 9,25 & kabuk böceği & 25 & 9,88 & doğal kızılçam & 15 & 7,50 \\
\hline baltalık ormanları & 27 & 9,25 & orman arazileri & 24 & 9,49 & Akdeniz ormanları & 14 & 7,00 \\
\hline biyolojik mücadele & 23 & 7,88 & orman fidanlığ 1 & 22 & 8,70 & odun hammaddesi & 12 & 6,00 \\
\hline ağaç kabukları & 23 & 7,88 & tohum ağacı & 19 & 7,51 & ekoturizm alanı & 11 & 5,50 \\
\hline ardıç ormanları & 22 & 7,53 & bitki türleri & 17 & 6,72 & biyolojik mücadele & 10 & 5,00 \\
\hline ağaçlandırma alanları & 20 & 6,85 & ormancilık kamuoyu & 14 & 5,53 & meşe ağacı & 10 & 5,00 \\
\hline ormancılık eğitimi & 20 & 6,85 & orman işletmeleri & 13 & 5,14 & k1zılçam ormanları & 9 & 4,50 \\
\hline
\end{tabular}

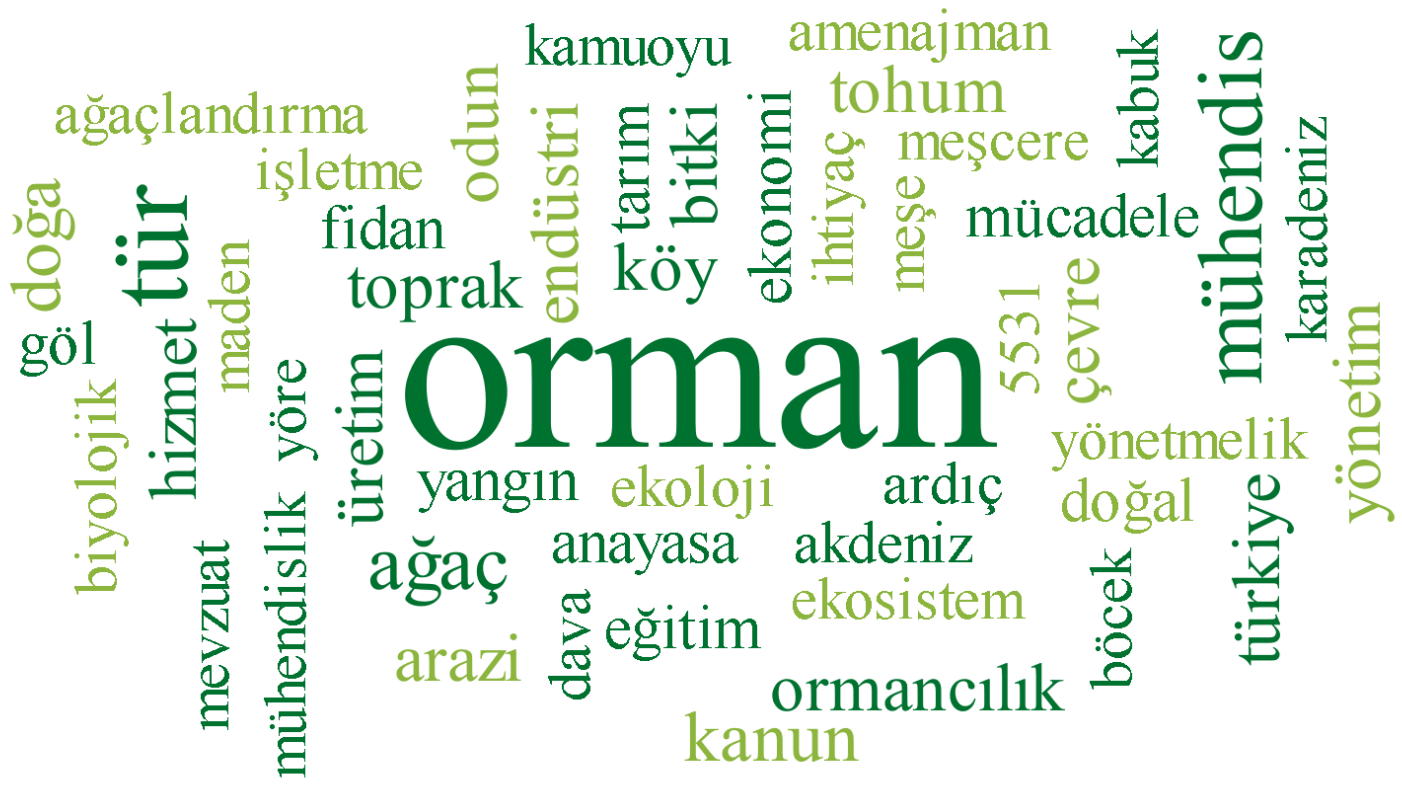

Şekil 1. 2005-2020 yılları arası kelime bulutu

2005-2020 yılları arası dergilerin içerikleri dikkate alınarak Şekil 1, Tablo 2'ye göre oluşturulmuştur. Kelime frekansı analizinden elde edilen sonuçlar değerlendirildiğinde en sık kullanılan sözcügün “orman” (n=9307) olduğu ve bu kelimenin kelime bulutundaki büyüklüğü de ç̧ekmektedir. 2005-2010 yılı dergilerinin kelime bulutunda mühendis $(n=2323)$, ağaç $(n=1696)$, ormancılık $(n=1519)$, toprak $(\mathrm{n}=1187) \mathrm{vb}$. kelimelerin ilk beşte yer aldığı görülmektedir. Bu kelimelerin sıklıkla kullanılmasının nedeni orman mühendisliği mesleği ile doğrudan ilişkili kelimeler olduğundan ve farklı konular içerisinde de kullanımının yoğunluğundan kaynaklandığı söylenebilir. 2011-2015 y1lları arasında en fazla kullanılan kelime öbeklerinin ilk beş tanesinin orman, mühendis, ormancılık, ağaç ve mühendislik olduğu görülmektedir. Çalışmada mühendis sözcügünden $(n=1491)$ defa bahsedilmiştir. Ayrıca, 2005- 
2020 yılları arası derginin içerik analizi ile elde edilen ilk 50 kelimeyi içeren kelime bulutu Şekil 2'de verilmiştir.

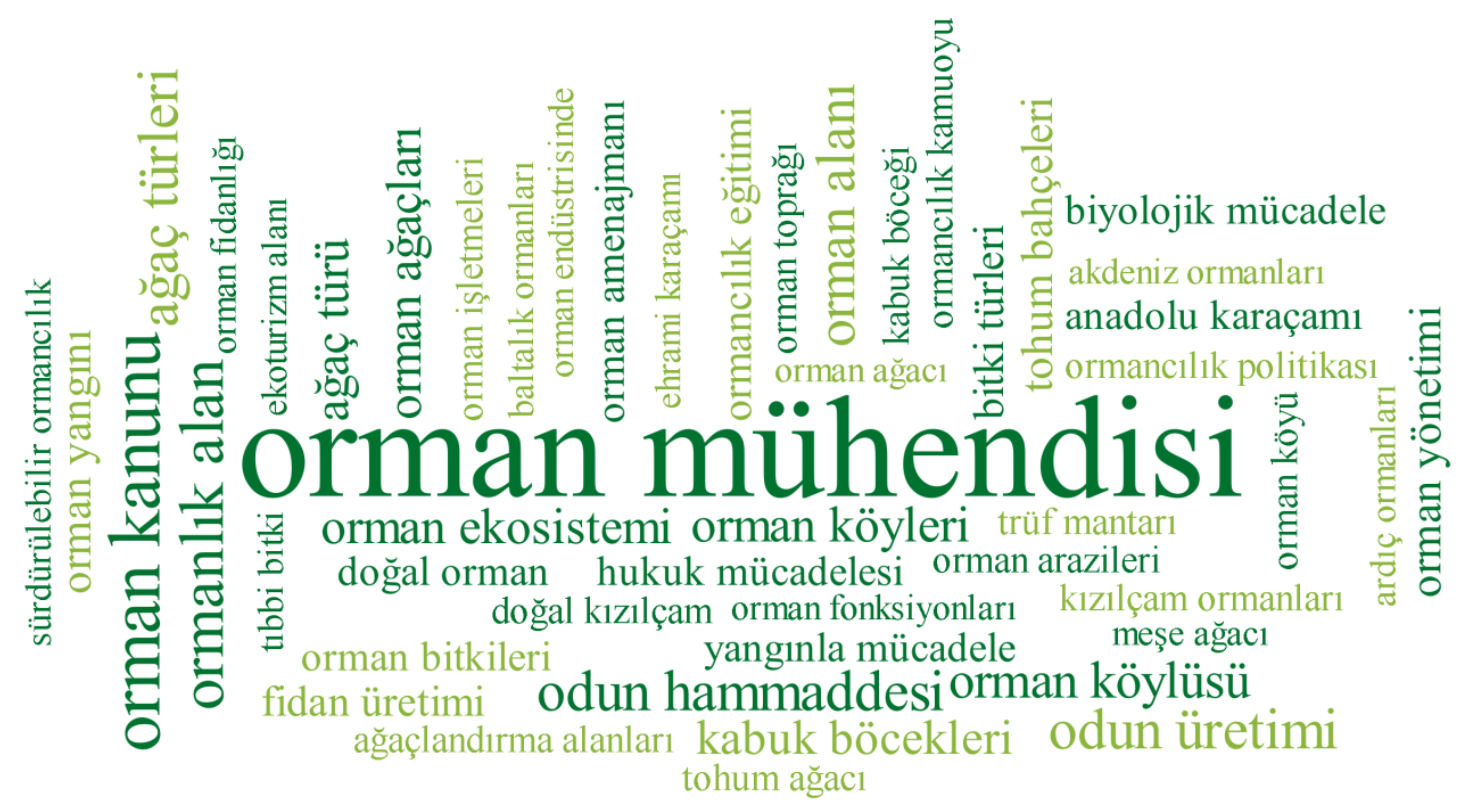

Şekil 2. 2005-2020 yılları arası derginin içerik analizi ile elde edilen kelime kombinasyonları bulutu

2005-2020 dergilerinin içerikleri dikkate alınarak Şekil 2, Tablo 3'e göre oluşturulmuştur. İlgili dergilerde en fazla kullanılan kelimeler ortaya konulmuștur. En sık kullanılan kelimeler arasında 20052010 yıllarında olduğu gibi 2011-2015 y1lları arasında orman $(n=8960)$ kelimesi, mühendis $(n=1491)$, ormanc1lık $(\mathrm{n}=1477)$, ağaç $(\mathrm{n}=1464)$, mühendislik $(\mathrm{n}=1342)$ ilk beş sırada olduğu belirlenmiştir. 20162020 yılları arası Orman Mühendisliği dergisinin (2018 yılından itibaren Yeşil Dünya Dergisinin) içerik analizine göre; en fazla kullanılan kelime öbeklerinin ilk beş tanesinin orman, ağaç, mühendis, tür ve doğa olduğu görülmektedir. Analize göre; 2016-2020 yılları arası dergilerde mühendis sözcügünden (n=1248) defa bahsedilmiştir. 2005-2010 ve 2011-2015 y1llarında olduğu gibi 2016-2020 yılları arasında da orman $(n=6153)$ kelimesinin en sık kullanılan kelime olduğu sonucuna ulaşılmıştır. 20162020 y1lı dergilerinin kelime bulutunda ağaç $(n=1357)$, mühendis $(n=1248)$, tür $(n=867)$, doğa $(n=710)$ vb. kelimeler ilk beşte yer aldığg görülmektedir.

2005-2020 yıllarının belirli periyotlarla kelime sıklı̆̆ına bakılmıştır ve çıkan sonuçlarda "orman" kelimesi ilk sırada yer almaktadır. Dağ [21] ormancılık alanında yapmış olduğu benzer bir araştırmada 837 lisansüstü tezi ele alarak içerik analizi ve kelime bulutları oluşturmuş̧tur. Araştırmacının elde ettiği sonuçlara bakıldığında, kelime frekansında orman kelimesinin ilk sırada yer alması bu çalışmanın bulgularıla benzerlik göstermektedir.

1960'lı yıllarda silvikültürel uygulamalar ve orman ekonomisi ile ilgili konulara ağırlıklı yer verilirken son yıllarda (Tablo 1'de yer alan 2011-2020 verileri) ele alınan bu konular silvikültür uygulamaları ve orman ekonomisi konularıdır. Ayrıca Tablo 1'de ele alınan konulardan "odadan haberler" ve "genel bilgiler" en çok yer alan konulardır. Milli parklar konusu en az bahsedilen konular arasında yer almasına rağmen periyotlar arası dikkat çeken farklar da görülmüş̧ür.

Analiz programının Türkçe karakter desteği ve formatı olmadığı için kelime analizlerinde bazı zorluklar yaşanmış ve hatalar ortaya çıkmıştır. Kaplan [25] sosyoloji alanında yaptığı çalışmada da bu sorunlardan bahsederek sadece Türkçe makaleleri ele almasına ve İngilizce yazılmış makaleleri araştırmaya dâhil edememesine yol açtığını ve çalışmada sadece "milli kavramlar" ele aldığını belirtmiştir. Fakat yapılan bu araştırmada yaşanan sorunlara rağmen daha fazla kelime ve kelime kombinasyonları ile çalışma yapılabilmiştir. 


\section{SONUC}

Bu çalışmada, Orman Mühendisliği ve Yeşil Dünya dergilerinin 1962-2020 yılları arasında yayımlanan sayıları içerik analizi yöntemi ile incelenmiş ve bilim dalları ve diğer ele alınan konuların sayıları arasındaki farklar ortaya konmuştur. Bu çalışma ile elde edilen veriler genel olarak değerlendirildiğinde aşağıdaki sonuçlara ulaşılmıştır:

1962-2020 yılları arasındaki dergilerde en çok odadan haberler ve genel konulara yer verildiği belirlenmiştir. Bilim dalları açısından ise en çok silvikültür, en az mera konularına değinildiği görülmüştür. Ayrıca, orman ekonomisi konusuna da ortalama her yıl dergilerde yer verildiği, fakat konu yoğunluğunun farklılık arz ettiği görülmüştür.

Dergilerde 13 farklı alanda konuya yer verilmiştir. Fakat bilim dalları bazında daha az konudan bahsedildiği görülmüştür. Daha dengeli olacak bir şekilde ormanc1lıkla ilgili her alandan konulara yer verilmesi okuyucular açısından yarar sağlayacağı düşülmektedir.

2005-2010 yılları arasındaki yapılan analize bakıldığında, en fazla kullanılan kelime öbeklerinin ilk beş

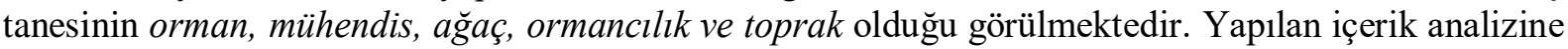
göre 2011-2015 yılları arasında en fazla kullanılan kelime öbeklerinin ilk beş tanesinin orman, mühendis, ormancılık, ağaç ve mühendislik olduğu tespit edilmiştir. 2015-2020 yılları arasında yapılan içerik analizinde ise; orman, ăgaç, mühendis, tür ve doğa kelimeleri en fazla kullanılan ilk beş kelime olarak çıkmıştır.

1962-2005 arası ele alınan konular ile 2005-2020 arası yapılan içerik analizinin konular bazında değerlendirildiğinde kelimeler arasında benzerlik olduğu görülmüsstür. En sık kullanılan ilk on kelimeye bakıldığında 5 tanesinin aynı olduğu görülmektedir. En sık kullanılan kelimelerin başında "orman" kelimesi yer almaktadır. Orman mühendisliği mesleği ve bu mesleğin ana uğraşı alanının orman alanları ve ormancılık faaliyetleri olması, bu kelimenin neden en sık kullanıldığını açıklamaktadır.

Dergilerin daha anlaşılır ve cezbedici olması için, ağılıklı olarak ormancılık alanına hitap etmesinin ötesinde ormancılık mesleği ile doğrudan ve dolaylı olan güncel konular olan iklim değiş̧ikliği ile mücadelenin güçlendirilmesi, doğa, çevre ve ekosistem hizmetleri kapsamında daha geniş tabanlı ele alınarak ve içeriğinin zenginleștirilerek derginin okuyucu kitlesinin farklı kesimler tarafından da dikkat çekmesi için çalışmalar başlatılmalıdır.

Dergilerde odadan haberlerin çok fazla yer aldığı dikkati çekmektedir. Bu konuda daha özet bilgiler verilerek okuyuculara daha fazla hitap eden ormancılık konularının olduğu, herkesin ilgisini çekebilecek konuların ve içeriklerinin ağırlığının arttırılması gerekmektedir.

Dergilerin ilk yılları arşivde saklanmakla birlikte dijital ortama aktarılmamıştır. Arşivde yer alan dergilerin bazılarında yıpranmalar meydana gelmiş ve okunmasının güç olduğu tespit edilmiştir. $\mathrm{Bu}$ yüzden dergilerin dijital ortama aktarılmasının gerekliliği görülmektedir. Böylece, dijital ortama aktarılan arşivin, Orman Mühendisleri Odası web sayfasında yayımlanarak ormancılık mesleğine ilişkin geçmişe dönük bilgilere erişimin kolaylaştırılması ve şeffaflığın sağlanması mümkün olacaktır.

$\mathrm{Bu}$ çalışmanın sonuçları, ormancılık alanında öncelikli olmak üzere dergilerden bilimsel araştırma yapacak olan kişilere genel bir içerik bilgisi verebileceği düşünülmektedir. Bu açıdan tanımlayıcı ve açıklayıcı bilgilerin yeni araştırmalar için fikir verici olduğu söylenebilir.

Bundan sonraki çalışmalarda, bilim dallarına göre ele alınan konular başta olmak üzere, dergilerin içeriklerinde ele alınan diğer konular, yazarların unvanı (akademisyen/orman mühendisi/diğer meslek vb.), üniversite, bölüm, bilim dalı, yazarların cinsiyeti, yaşı, vb. farklı değişkenlere göre dergi içeriğindeki tarihsel değişimler ve farklılıklar da dikkate alınarak istatistiki çözümlemeler ile araştırılabilir. 
Araştırmada faydalanılan içerik analizi yöntemi istenilen sonuca ulaşmada katkı sağlamıştır. Yapılan bu çalışmadaki gibi yazılı ve uzun süreli kaynaklar ile ilgili yapılacak çalışmalarda bu yöntemin uygulanması önerilmektedir.

Bu çalışmada veri elde etme aşaması oldukça güç ve zaman alıcı olmuştur. Analiz programı kelimeleri tam kelime olarak değil, kelime içindekileri de okuyarak analiz sonuçlarının yanlış yorumlanabilmesi risklerini içerebilmektedir. Bunların kontrolü ve ayrımı oldukça zaman alıcıdır. Ayrıca bazı kelimelerin program tarafindan okunamamas1 ya da yabanc1 kelime olarak algılayabilmesi sorunları da ortaya çıkabilmektedir. Bu da yapılan çalışmalarda zorluklar yaşanmasına ve hatalı analiz ve yorumlara yol açabilmektedir. MAXQDA 2020 programının Türkçe formatının da olması ve programdan kaynaklanan bu hataların düzeltilerek kullanıcılara sunulması araştırmacılar açısından kolaylaştırıcı olacaktır.

\section{KAYNAKLAR}

[1] R. Coşkun, R. Altunışık ve E. Yıldırım, Sosyal Bilimlerde Araştırma Yöntemleri SPSS Uygulamall, 9. Bask1, Sakarya, Türkiye: Sakarya Yayıncılık, 2017, ss. 1-16.

[2] I. Ç. Erdönmez, "Türkiye'de yayıncılık politikalarının dönüşümü üzerine bir örnek: Eyayınc1lı," Bilişim Teknolojileri Online Dergisi, c. 5, s. 17, ss. 45-56, 2014.

[3] TDK, Türk Dil Kurumu sözlükleri yazılı medya istatistikleri, [Çevrimiçi]. Erişim Adresi: https://www.sozluk.gov.tr/, Erişim Tarihi: 20.12.2019.

[4] E. Yüksel ve H. İ. Gürcan, Habercinin el rehberi: soru ve örneklerle haber toplama ve yazma kural ve teknikleri, Eskişehir, Türkiye: Anadolu Üniversitesi İletişim Bilimleri Fakültesi Yayınları, 2001, ss. 1-77.

[5] S. Biçer, “Türkiye'de internet yayıncılığı ve Avrupa Birliği’ne uyum,” Yayımlanmamış Yüksek Lisans Tezi, Radyo-Televizyon ve Sinema Anabilim Dalı, Sosyal Bilimler Enstitüsü, Gazi Üniversitesi, Ankara, Türkiye, 2006.

[6] A. Altun, Türkiye'de Gazetecilik ve Gazeteciler, Ankara, Türkiye: Çağdaş Gazeteciler Derneği Yayınlar1, 1995, ss. 110.

[7] H. İ. Gürcan ve Ç. Batu, "Haber sitelerinde içerik kalitesine yönelik bir analiz," Türkiye'de Internet Konferansı, İstanbul, Türkiye, 2002, ss. 1-7.

[8] Y. Tonta ve U. Al, "Türkiye'nin bilimsel yayın haritası: Türkiye'de dergi yayıncılı̆̆ üzerine bibliyometrik bir araştırma," Hacettepe Üniversitesi, Bilgi ve Belge Yönetimi Bölümü, Ankara, Türkiye, Rap. SOBAG-105K088, 2007.

[9] H. Şimşek, “XIX. yüzyıl çocuk dergiciliği ve eğitsel işlevleri üzerine,” Milli Eğitim Dergisi, c. 151, s. 3, ss. 1-9, 2001.

[10] H. R. Ertuğ, Basın ve Yayın Hareketleri Tarihi, İstanbul, Türkiye: Sulhi Garan Matbaası, c. 1, Yayin No: 1492, 1959, ss. 1-190.

[11] B. Yurtoğlu, "Türkiye'de ormancılık alanında yayınlanan ilk Osmanlıca makale," Kastamonu Üniversitesi Orman Fakültesi Dergisi, c. 14, s. 2, ss. 173-181, 2014. 
[12] TÜİK, Türkiye İstatistik Kurumu yazılı medya istatistikleri, [Çevrimiçi]. Erişim Adresi: https://data.tuik.gov.tr/Bulten/Index?p=Yazili-Medya--Istatistikleri-2019-33620, Erişim Tarihi: 10.06.2020.

[13] C. Gümüş, Türk Orman Devrimi, Ankara, Türkiye: Dönmez Ofset, 2018, ss. 1-306.

[14] S. Özden ve F. Ekici, “Orman mühendisliği mesleğinin dünü, bugünü ve geleceği," III. Ulusal Karadeniz Ormancllı Kongresi, Artvin, Türkiye, 2010, ss. 17-23.

[15] Ü. Aktan, "Serbest ormanc1lı büroları ve orman mühendisi istihdamına etkisi," Yayımlanmamış Yüksek Lisans Tezi, Orman Mühendisliği Anabilim Dalı, Fen Bilimleri Enstitüsü, Artvin Çoruh Üniversitesi, Artvin, Türkiye, 2013.

[16] M. Ünal, T. Türkoğlu ve A. Tolunay, "Orman mühendislerinin mesleki örgütlenmeye bakış açıları," Süleyman Demirel Üniversitesi Fen Bilimleri Enstitüsü Dergisi, c. 22, s. 1, ss. 165-171, 2018.

[17] OMO, Hakkımızda, Orman Mühendisleri Odası, [Çevrimiçi]. Erişim Adresi: https://ormuh.org.tr/tarihce, Erişim Tarihi: 30.12.2018.

[18] OMO, “Orman Mühendisliği dergisi çıkarken,” Orman Mühendisliği Dergisi, c. 1, s. 3, ss. 1-5, 1962.

[19] N. Bilgin, Sosyal Bilimlerde İçerik Analizi: Teknikler ve Örnek Çalışmalar, 2. Baskı, Ankara, Türkiye: Siyasal Kitabevi, 2006, ss. 1-230.

[20] N. Bilgin, Sosyal Bilimlerde İçerik Analizi: Teknikler ve Örnek Çalışmalar, 4. Baskı, Ankara: Siyasal Kitabevi, 2014, ss. 1-272.

[21] F. Dă̆, "Ormancılık alanında yapılmış olan lisansüstü tezler: Orman ekonomisi merkezli bir içerik analizi," Yüksek Lisans Tezi, Orman Mühendisliği Anabilim Dalı, Fen Bilimleri Enstitüsü, Düzce Üniversitesi, Düzce, Türkiye, 2019.

[22] U. Kuckartz ve Stefan Rädiker, Analyzing Qualitative Data with MAXQDA, 1. Bask1, Switzerland: Springer, 2019, ss. 1-290.

[23] C. Aslan, "Bir Osmanlı kadın gazetesi: Sıyanet (içerik analizi)," Yüksek Lisans Tezi, Atatürk İlkeleri ve İnkılap Tarihi Enstitüsü, İstanbul Üniversitesi, İstanbul, Türkiye, 2019.

[24] Ö. Çelikel, “Türkiye'de yayınlanmış sosyoloji dergilerinin içerik analizi,” Yüksek Lisans Tezi, Sosyal Bilimleri Enstitüsü, Uludağ Üniversitesi, Bursa, Türkiye, 2011.

[25] A. Kaplan, "Sosyoloji konferansları dergisinin içerik analizi," Yüksek Lisans Tezi, Sosyal Bilimleri Enstitüsü, Gazi Üniversitesi, Ankara, Türkiye, 2019. 